\title{
Article \\ Quantification of Typhoon-Induced Phytoplankton Blooms Using Satellite Multi-Sensor Data
}

\author{
Jiayi Pan ${ }^{1,2,3, *(\mathbb{D}}$, Lei Huang ${ }^{2}$, Adam T. Devlin ${ }^{2}$ and Hui Lin ${ }^{2}$ \\ School of Marine Sciences, Nanjing University of Information Science and Technology, Nanjing 210044, China \\ 2 Institute of Space and Earth Information Science, The Chinese University of Hong Kong, Hong Kong, China; \\ huangleigdo@126.com (L.H.); phlux1@gmail.com (A.T.D.); huilin@cuhk.edu.hk (H.L.) \\ 3 Shenzhen Research Institute, The Chinese University of Hong Kong, Shenzhen 518057, China \\ * Correspondence: panj@cuhk.edu.hk; Tel.: +852-3943-1308
}

Received: 19 December 2017; Accepted: 16 February 2018; Published: 20 February 2018

\begin{abstract}
Using satellite-based multi-sensor observations, this study investigates Chl-a blooms induced by typhoons in the Northwest Pacific (NWP) and the South China Sea (SCS), and quantifies the blooms via wind-induced mixing and Ekman pumping parameters, as well as pre-typhoon mixed-layer depth (MLD). In the NWP, the Chl-a bloom is more correlated with the Ekman pumping than with the other two parameters, with an $\mathrm{R}^{2}$ value of 0.56 . In the SCS, the wind-induced mixing and Ekman pumping have comparable correlations with the Chl-a increase, showing $R^{2}$ values of 0.4 0.6. However, the MLD exhibits a negative correlation with the Chl-a increase. A multi-parameter quantification model of the Chl-a bloom strength achieves better results than the single-parameter regressions, yielding a more significant $R^{2}$ value of 0.80 , and a lower regression $\mathrm{rms}$ of $0.18 \mathrm{mg} \cdot \mathrm{m}^{-3}$ in the SCS, and the $\mathrm{R}^{2}$ value in the NWP is also improved compared with the single-parameter regressions. The multi-parameter quantification model of Chl-a blooms is more accurate in the SCS than in the NWP, due to the fact that nutrient profiles in the NWP are uniform from surface to a deep depth $(300 \mathrm{~m})$. Thus, the Chl-a blooms are more correlated with the upper ocean dynamical processes in the SCS where a shallower nutricline is found.
\end{abstract}

Keywords: phytoplankton bloom; typhoon; wind forcing; ekman pumping; mixed-layer depth

\section{Introduction}

Tropical cyclones (a rapidly rotating storm system) occur frequently over the tropical and subtropical oceans, accompanied by strong winds that can significantly influence upper ocean dynamics [1-5]. Strong cyclonic systems that form in the Northwest Pacific are known as typhoons. The strong forcing of tropical cyclone or typhoon winds produces two kinds of dynamic responses in the upper ocean, namely turbulent mixing and upwelling, both of which can induce a decrease of sea surface temperature (SST). Typical cyclone-induced SST decreases range from 1 to $6{ }^{\circ} \mathrm{C}$ [1], though more intensive cooling $\left(9^{\circ} \mathrm{C}\right)$ was observed for Typhoon Kai-Tak in the South China Sea (SCS) [6]. Additionally, under the influence of Typhoon Lupit in the Northwest Pacific (NWP), maximum surface cooling reached $7{ }^{\circ} \mathrm{C}$ on 25 October 2009 , which was associated with an expansion of the cooling area and negative sea surface height anomaly [7]. The range of temperature drop depends on typhoon intensity and translation speed, and the ocean response is much different for fast- and slow-moving typhoons [2,8].

Another important dynamical phenomenon related to tropical cyclones is mixed-layer deepening as a result of mixing and upwelling processes. Hurricane Felix in the Atlantic from 13-23 August 1995 caused cooling in the upper $30 \mathrm{~m}$ and warming at depths of 30-70 m due to significant mixed-layer deepening and vertical redistribution of temperature resulting from heat diffusion, as simulated by a 
one-dimensional mixed layer model [9]. Under the influence of Hurricane Gilbert (in the Atlantic), the vertical mixing in the upper ocean is a dominant mechanism controlling heat and mass budgets and vertical heat and mass distributions [10,11]. Based on mixing effects, Pan and Sun developed a diagnostic model to estimate the increase in mixed-layer depth in the South China Sea caused by Typhoon Cimaron using satellite data, which presented an effective methodology for extending the capability of satellite observations from the ocean surface to the sub-surface [12].

Since the forcing of tropical cyclone winds can induce strong ocean mixing and upwelling, nutrients in the sub-surface can be brought into the ocean surface layer, enhancing photosynthesis and boosting primary productivity at the ocean surface [4,13-15]. After the passage of tropical cyclones, sufficient light provides favorable conditions for the growth of phytoplankton in the upper ocean. Even in the oligotrophic ocean, chlorophyll-a (Chl-a) concentration increases significantly at the surface of cooling areas after the passage of a cyclone, with nutrient-rich water uplifted into the surface layer [13]. The augmentation of chlorophyll-a usually may last about two weeks after the cyclone passes $[16,17]$, as does the surface cooling. In the SCS, tropical cyclones contribute $20-30 \%$ of the annual new primary production $[4,18]$.

The pre-typhoon mixed-layer depth is another factor affecting both the dynamic response of the upper ocean to the strong forcing of tropical cyclone winds and the marine biochemical response. The mean state of the climatological mixed-layer depth can be easily modified by eddies $[19,20]$. Cyclonic eddies uplift the subsurface temperature profile and thin the mixed-layer, while anti-cyclonic eddies push the isotherms downward and thicken the mixed-layer [12,19-21]. With a shallow mixed-layer, the deep nutrient-rich water can easily be uplifted, enhancing the phytoplankton bloom [22].

Phytoplankton blooms induced by the strong forcing of tropical cyclone winds may be attributed to multiple factors related to the cyclone characteristics and ocean conditions. In this study, we develop a quantification model of the phytoplankton blooms, which links Chl-a increase with typhoon-related parameters (wind speed, typhoon influence duration, etc.) and oceanic pre-typhoon conditions, which can reveal the sensitivity of the $\mathrm{Chl}-\mathrm{a}$ change to various parameters. The model is based on the analysis of satellite-based multi-sensor data and other relevant typhoon observations, which paves the way for better understanding of the mechanisms of the typhoon-induced phytoplankton bloom under various oceanic conditions.

\section{Data}

\subsection{Chl-a Data}

Daily merged Chl-a products at $4 \mathrm{~km}$ resolution are obtained from the GlobColour system (http://hermes.acri.fr/). The GlobColour project started in 2005 as an ESA Data User Element (DUE) project, which provides a long time series (10 years) of daily merged Level 3 products. The GlobColour Chl-a product combines multiple satellite observations including those from the Medium Resolution Imaging Spectrometer Instrument (MERIS) aboard the Environmental Satellite (ENVISAT), the Moderate Imaging Spectrometer (MODIS) on the Aqua Earth Observing System (EOS) mission, and the Sea-viewing Wide Field of view Sensor (SeaWiFS) on board OrbView-2 satellite (renamed from SeaStar in 1997).

To determine Chl-a blooms after passages of typhoons (or storms), the areas showing maximum increases of Chl-a concentration along the typhoon (or storm) tracks are identified in satellite images. Figure 1 displays an instance of a Chl-a bloom in the SCS that was affected by a typhoon event (Ketsana in 2009). The black box shows the area of maximum Chl-a increase. Ketsana in 2009 originated from a tropical depression in the northwestern Pacific $\left(128.80^{\circ} \mathrm{E}, 14.30^{\circ} \mathrm{N}\right)$ at 00:00 UTC on 25 September 2009 and strengthened to a category 1 typhoon with a maximum sustained wind (MSW) speed of $41 \mathrm{~m} \cdot \mathrm{s}^{-1}$ when it arrived east of Vietnam at 06:00 UTC on 28 September, with a mean translation speed of $4.2 \cdot \mathrm{m} \mathrm{s}^{-1}$. Before the typhoon passed, the Chl-a level was low. After the typhoon, Chl-a concentration 
was substantially elevated southeast of Hainan Island on 1-2 October 2009 (Figure 1a). The maximum Chl-a concentration (Chl- $\left.a_{\max }\right)$ is determined (in the black box in Figure 1a), and the pixels showing Chl-a concentration in the range of (0.5 1.0)Chl- $a_{\text {max }}$ are selected (Figure 1b; 2 October 2009), and the average $\mathrm{Chl}$-a concentration is calculated for this region. The Chl-a concentration in the range of (0.5 1.0)Chl- $a_{\max }$ represents the value of a significant Chl-a bloom. Therefore, the Chl-a average for this region is defined as the daily elevated Chl-a value as induced by the typhoon forcing.

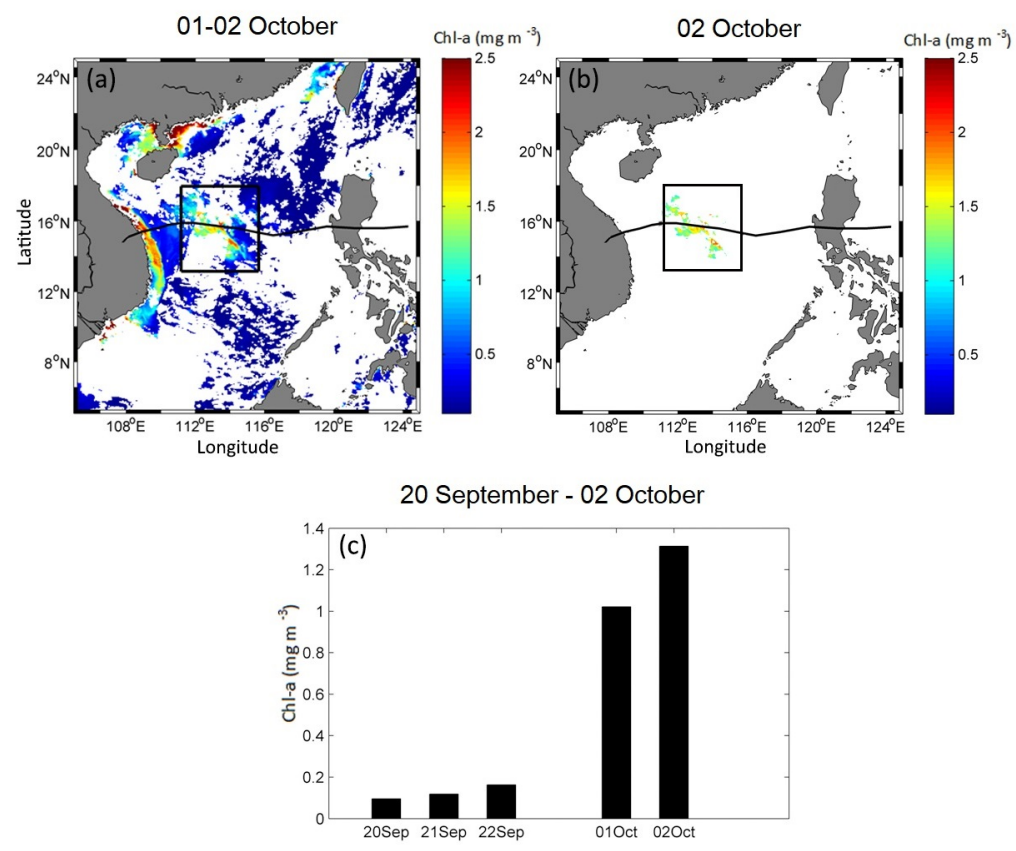

Figure 1. Chl-a blooms in the SCS as affected by Ketsana in 2009 (on 1-2 October 2009); the black box shows the area of the highest Chl-a increase (a). The pixels of the Chl-a concentration in the range of (0.5 1.0)Chl- $a_{\max }(\mathbf{b})$. The time series of daily Chl-a concentrations on 1-2 October 2009 after the passage of the typhoon and the pre-typhoon Chl-a concentration (20-22 September 2009) (c).

Data gaps can be an issue limiting daily Chl-a images due to cloud cover. To overcome this deficiency in the daily images (for each typhoon case), we derive a time series of daily Chl-a concentrations for the timespan of existence of the high Chl-a level (October 1-2 for Ketsana in 2009) after the typhoon passage (Figure 1c), and the average is calculated as the elevated Chl-a concentration. The background Chl-a before the typhoon passage is obtained from the average of the Chl-a concentration before the typhoon event in the area shown in the black box for the 3 days (20-22 September 2009, Figure 1c). The Chl-a concentration increase $(\Delta C h l)$ is derived by removing the background Chl-a from the elevated Chl-a values after the typhoon passage. In this manner, the Chl-a concentration increase is calculated for each typhoon (or storm) case in this study (listed in Tables 1 and 2). 
Table 1. Summary of typhoon cases and relevant parameters in the Northwest Pacific (NWP) in the years from 2002 to 2009.

\begin{tabular}{|c|c|c|c|c|c|}
\hline $\begin{array}{l}\text { Typhoon } \\
\text { Cases }\end{array}$ & Date & $\begin{array}{c}\Delta C h l \\
\left(\mathrm{mg} \cdot \mathrm{m}^{-3}\right)\end{array}$ & $\begin{array}{l}\text { Ekman Pumping } \\
\left(L_{E K M}, \mathrm{~m}\right)\end{array}$ & $\begin{array}{l}\text { Wind Power } \\
\left(E_{W}, \mathrm{~J} \cdot \mathrm{m}^{-2}\right)\end{array}$ & $\begin{array}{l}H_{M L D} \\
\text { (m) }\end{array}$ \\
\hline Rammasun & 28 June-6 July 2002 & 0.10 & 21.8 & 58.9 & 24.1 \\
\hline Fung-wong & 20-27 July 2002 & 0.02 & 7.7 & 17.1 & 40.2 \\
\hline Etau & 3-9 August 2003 & 0.08 & 13.4 & 37.8 & 15.4 \\
\hline Maemi & 5-13 September 2003 & 0.03 & 8.5 & 33.1 & 35.5 \\
\hline Dianmu & 13-21 June 2004 & 0.03 & 15.4 & 31.3 & 19.4 \\
\hline Rananim & 7-13 August 2004 & 0.06 & 14.1 & 42.1 & 33.7 \\
\hline Nesat & 30 May-10 June 2005 & 0.08 & 13.2 & 36.4 & 13.9 \\
\hline Haitang & 11-19 July 2005 & 0.07 & 14.4 & 76.9 & 33.5 \\
\hline Talim & $\begin{array}{l}26 \text { August-1 } \\
\text { September } 2005\end{array}$ & 0.05 & 5.9 & 18.3 & 32.9 \\
\hline Ewiniar & 29 June-10 July 2006 & 0.07 & 9.0 & 45.8 & 36.7 \\
\hline Kaemi & 18-25 July 2006 & 0.03 & 11.0 & 30.3 & 35.2 \\
\hline Shanshan & 10-17 September 2006 & 0.14 & 27.3 & 107.2 & 13.2 \\
\hline Man-yi & 8-15 July 2007 & 0.04 & 11.7 & 27.6 & 13.7 \\
\hline Usagi & 28 July-3 August 2007 & 0.03 & 10.1 & 33.1 & 26.5 \\
\hline Sepat & 12-19 August 2007 & 0.11 & 23.4 & 54.5 & 33.5 \\
\hline Pabuk & 5-9 August 2007 & 0.06 & 4.7 & 18.6 & 23.8 \\
\hline Fitow & $\begin{array}{l}28 \text { August-7 } \\
\text { September } 2007\end{array}$ & 0.12 & 13.4 & 40.7 & 23.5 \\
\hline Morakot & 3-9 August 2009 & 0.09 & 14.5 & 37.5 & 16.8 \\
\hline Etau & 6-14 August 2009 & 0.02 & 4.9 & 13.2 & 22.7 \\
\hline
\end{tabular}

Table 2. Summary of typhoon cases and relevant parameters in the South China Sea (SCS) in the years from 2003 to 2009.

\begin{tabular}{|c|c|c|c|c|c|}
\hline $\begin{array}{l}\text { Typhoon } \\
\text { Cases }\end{array}$ & Date & $\begin{array}{c}\Delta C h l \\
\left(\mathrm{mg} \cdot \mathrm{m}^{-3}\right)\end{array}$ & $\begin{array}{l}\text { Ekman Pumping } \\
\left(L_{E K M}, \mathrm{~m}\right)\end{array}$ & $\begin{array}{l}\text { Wind Power } \\
\left(E_{W}, \mathrm{~J} \cdot \mathrm{m}^{-2}\right)\end{array}$ & $H_{M L D}(\mathrm{~m})$ \\
\hline Imbudo & 16-24 July 2003 & 0.24 & 11.2 & 20.6 & 23.5 \\
\hline Krovanh & 15-25 August 2003 & 0.09 & 16.2 & 34.3 & 37.2 \\
\hline Dujuan & $\begin{array}{l}30 \text { August-3 } \\
\text { September } 2003\end{array}$ & 0.11 & 3.0 & 8.7 & 25.3 \\
\hline Chanthu & 9-13 June 2004 & 0.11 & 22 & 26.2 & 26.8 \\
\hline Kompasu & 13-16 July 2004 & 0.14 & 2.3 & 1.9 & 25.6 \\
\hline Sanvu & 10-13 August 2005 & 0.24 & 15.2 & 38.4 & 36.7 \\
\hline Vicente & 16-18 September 2005 & 0.16 & 27.9 & 31.3 & 35.2 \\
\hline Damrey & 21-27 September 2005 & 0.96 & 28.6 & 53.4 & 25.1 \\
\hline Chanchu & 8-18 May 2006 & 1.31 & 35.6 & 90.5 & 17.7 \\
\hline Jelawat & 26-29 June 2006 & 0.08 & 2.3 & 2.1 & 25.3 \\
\hline Prapiroon & 31 July-3 August 2006 & 0.31 & 29.5 & 30.7 & 24.6 \\
\hline Xangsane & 25-30 September 2006 & 0.68 & 20.3 & 20.9 & 22.9 \\
\hline TD \#06W & 1-7 August 2007 & 0.16 & 3.5 & 10.6 & 15.4 \\
\hline Fengshen & 17-25 June 2008 & 0.22 & 12.3 & 29.1 & 35.5 \\
\hline Kammuri & 3-7 August 2008 & 0.20 & 9.8 & 15.5 & 15.4 \\
\hline Nuri & 16-23 August 2008 & 0.50 & 23.8 & 47.4 & 34.9 \\
\hline Hagupit & 17-25 September 2008 & 0.65 & 27.7 & 59.9 & 27.6 \\
\hline Linfa & 13-22 June 2009 & 0.48 & 22.4 & 26.1 & 34.1 \\
\hline Koppu & 11-15 September 2009 & 0.42 & 21.6 & 56.6 & 26.7 \\
\hline Ketsana & 25-29 September 2009 & 1.04 & 23.8 & 44.2 & 15.9 \\
\hline
\end{tabular}

\subsection{Sea Surface Wind}

Daily sea surface winds with a spatial resolution of $0.25^{\circ} \times 0.25^{\circ}$ are assembled from the Quick Scatterometer (QuikScat) data provided by Remote Sensing Systems (http://www.remss. com/). The Quick Scatterometer was launched in June 1999 and had been in operation until 
November 2009. This instrument is referred to as QuikScat (or QSCAT) to distinguish it from the nearly identical SeaWinds scatterometer on the same satellite platform Midori-2 (known to US scientists as ADEOS-II). The primary mission of these scatterometers was to measure winds near the ocean surface. The QuikScat data provided by the Remote Sensing Systems used a newly developed Ku-2011 GMF with WindSat data as a calibration target, which enhances validity of the wind product under storm conditions [23]. The daily wind data are chosen from satellite-derived winds at the center of the areas with maximum increase of Chl-a concentration (e.g., the black box in Figure 1a).

\subsection{Mixed-Layer Depth}

The mixed-layer depth is derived from temperature profiles, provided by the European Copernicus Marine Environment Monitoring Service. Copernicus is a European Union program, aiming to develop European information services based on satellite Earth Observation and in situ data [24].The dataset of Global Observed Ocean Physics Temperature Salinity Heights and Currents Reprocessing combines products from satellite observations (sea level anomalies, geostrophic surface currents, sea surface temperature) and in situ data (temperature and salinity profiles) on a $1 / 4$ degree regular grid for the global oceans over the time period 1993-2014. Calibrations and validations have been performed and results show overall good accuracy $[25,26]$. Weekly and monthly products are available from the dataset; in this study weekly temperature profiles before each typhoon at the center of the areas with maximum increase of the Chl-a concentration are used to extract the mixed-layer depth at which the sharp temperature gradient appears. The temperature profiles are downloaded from the Copernicus website [24].

\subsection{Typhoon Data}

The typhoon data are obtained from the Unisys Weather [27], which incorporates the best storm tracks from the Joint Typhoon Warning Center in the USA. We select 19 typhoons (or lesser intensity storms) in the NWP and 20 in the SCS that occurred in summer (June-September) during 2002-2009 to analyze Chl-a responses in the upper ocean after the typhoon passes (Tables 1 and 2). All the relevant typhoon tracks in the NWP (a) and the SCS (b) are shown in Figure 2, which also illustrates the study areas (the cyan boxes) in the NWP and the SCS. The red squares show the locations of the maximum Chl-a increases after the typhoon passes. No other typhoons (or storms) passed over the same regions two to three weeks before each of the selected typhoon, which ensures that the upper ocean was relatively stable and not disturbed by previous storm events.
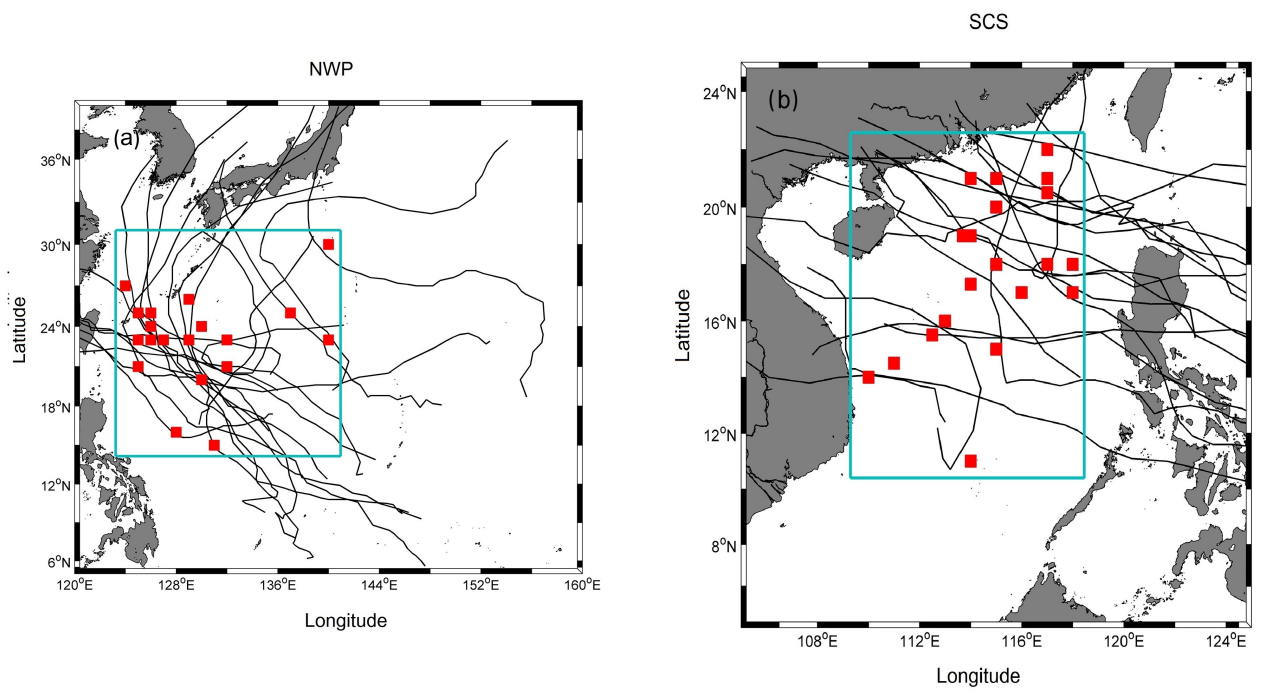

Figure 2. The typhoon tracks and the study areas in the NWP (a) and the SCS (b). The red squares show the locations with the maximum $\mathrm{Chl}$-a increases after the typhoon passes along these typhoon tracks. 


\section{Methods}

Tropical cyclone-induced upwelling is one of the most important factors influencing the transport of essential nutrients from the sub-surface water to the oligotrophic surface layer in open oceans. Cumulative effects of the upwelling can be quantified by the integral of the Ekman pumping velocity $\left(L_{E K M}\right)$, given by

$$
L_{E K M}=\int_{t_{1}}^{t_{2}} w_{e} d t
$$

where $t_{1}$ and $t_{2}$ represent the beginning and ending time of the typhoon influence period, respectively, and $w_{e}$ is the Ekman pumping velocity, defined as

$$
w_{e}=\operatorname{curl}_{z}\left(\frac{\tau}{\rho_{w} f}\right)
$$

where $\rho_{w}$ is the seawater density, $f$ is the Coriolis parameter, and $\tau$ is the wind stress on the ocean surface

$$
\tau=\rho_{a} C_{D} U_{10}^{2}
$$

where $\rho_{a}\left(=1.3 \mathrm{~kg} \mathrm{~m}^{-3}\right)$ is the air density, $C_{D}=10^{-3} \times\left(0.6+0.07 U_{10}\right)$ is the drag coefficient, and $U_{10}$ is the wind speed at $10 \mathrm{~m}$ height above the sea surface as derived from the QuikScat wind product.

The surface layer mixing may break through the stratification layer and bring the surface nutrients up to the surface layer caused by wind stirring [1,28]. The wind stirring-caused mixing is proportional to the wind power input, given by [29].

$$
P_{w}=\tau U_{10}=\rho_{a} C_{D} U_{10}{ }^{3}
$$

The temporal integral of the wind power input (indicating the effects of wind stirring) is defined as

$$
E_{w}=\int_{t_{1}}^{t_{2}} P_{w} d t
$$

The $L_{E K M}$ and $P_{w}$ are calculated for the typhoon cases in the NWP and the SCS listed in Tables 1 and 2, respectively.

\section{Results}

Figure 3 shows the Chl-a increase after typhoon passages versus the Ekman pumping parameter. High correlations are found between the Chl-a increase $(\Delta C h l)$ and the Ekman pumping parameter $\left(L_{E K M}\right)$ using a linear regression for both the NWP and the SCS. In the NWP, the linear regression is given by

$$
\Delta C h l=0.0044 L_{E K M}+0.0081
$$

Table 3 lists the regression coefficients and bounds of the regression coefficients at the $95 \%$ confidence level. The $\mathrm{R}^{2}$ value of the linear regression reaches 0.56 , and the root mean square (rms) of the Chl-a regression (namely, the rms of the difference between the Chl-a increase and the regression data) is $0.024 \mathrm{mg} \cdot \mathrm{m}^{-3}$ (Table 3). For the SCS, the regression is derived as

$$
\Delta \mathrm{Chl}=0.0240 L_{E K M}-0.0258
$$

The $\mathrm{R}^{2}$ value is 0.47 , lower than that in the NWP, while the rms of the Chl-a increase regression is $0.27 \mathrm{mg} \cdot \mathrm{m}^{-3}$ (Table 3). Comparison between the two regressions given by Equations (6) and (7) suggests that the Chl-a increase in the SCS is much ( 5.5 times) higher than that in the NWP under the same Ekman pumping intensity. 
The Chl-a increase versus the wind power input parameter, $E_{W}$ is shown in Figure 4 for the NWP (a) and the SCS (b). The linear regression for the NWP is derived as follows

$$
\Delta C h l=0.0012 E_{W}+0.0183
$$
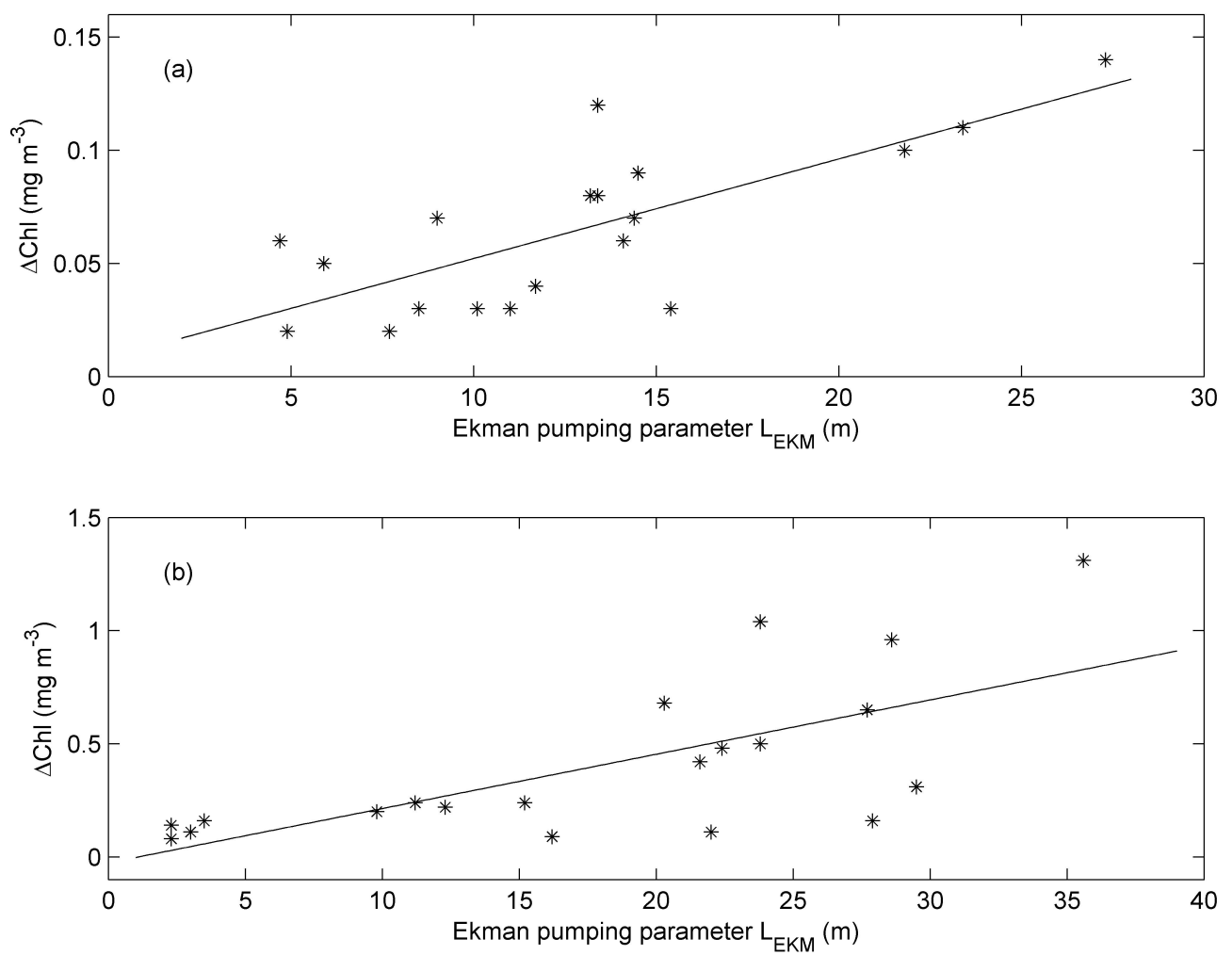

Figure 3. Linear regression of Chl-a increase to Ekman pumping parameter, $L_{E K M}$ in the NWP (a) and the SCS (b). The asterisks show the observations and the solid lines are the regressions.

Table 3. Linear regression results for Ekman pumping, wind-induced mixing, and mixed-layer depth parameters. $\Delta$ Chl-a $=p 1\left(L_{E K M}, E_{W}\right.$, or $\left.H_{M L D}\right)+p 2$.

\begin{tabular}{cccccccc}
\hline $\begin{array}{c}\text { Regression } \\
\text { Parameter }\end{array}$ & Region & $\boldsymbol{p 1}$ & $\begin{array}{c}\mathbf{9 5 \%} \text { Confidence } \\
\text { Level }\end{array}$ & $\boldsymbol{p 2}$ & $\begin{array}{c}\mathbf{9 5 \%} \text { Confidence } \\
\text { Level }\end{array}$ & $\mathbf{R}^{\mathbf{2}}$ & $\begin{array}{c}\mathbf{R M S} \\
\left(\mathbf{m g} \cdot \mathbf{m}^{-3} \text { ) }\right.\end{array}$ \\
\hline \multirow{2}{*}{$L_{E K M}$} & NWP & 0.0044 & $0.0024,0.0064$ & 0.0081 & $-0.0200,0.0362$ & 0.56 & 0.024 \\
& SCS & 0.0240 & $0.0114,0.0366$ & -0.0258 & $-0.2841,0.2324$ & 0.47 & 0.27 \\
$E_{W}$ & NWP & 0.0012 & $0.0006,0.0017$ & 0.0183 & $-0.0069,0.0436$ & 0.54 & 0.025 \\
& SCS & 0.0125 & $0.0074,0.0176$ & 0.0003 & $-0.1983,0.1989$ & 0.59 & 0.23 \\
$H_{M L D}$ & NWP & -0.0014 & $-0.0033,0.0005$ & 0.1020 & $0.0498,0.1542$ & 0.13 & 0.034 \\
& SCS & -0.0176 & $-0.0406,0.0054$ & 0.8725 & $0.2420,1.5030$ & 0.13 & 0.34 \\
\hline
\end{tabular}

The $\mathrm{R}^{2}$ value reaches 0.54 , and the rms of the Chl-a increase regression is $0.025 \mathrm{mg} \cdot \mathrm{m}^{-3}$ (Table 3). For the SCS, the regression is given by

$$
\Delta C h l=0.0125 E_{W}+0.0003
$$

with a $\mathrm{R}^{2}$ value of 0.59 , and an rms of the difference between Chl-a data and the regressions of $0.23 \mathrm{mg} \cdot \mathrm{m}^{-3}$ (Table 3). 

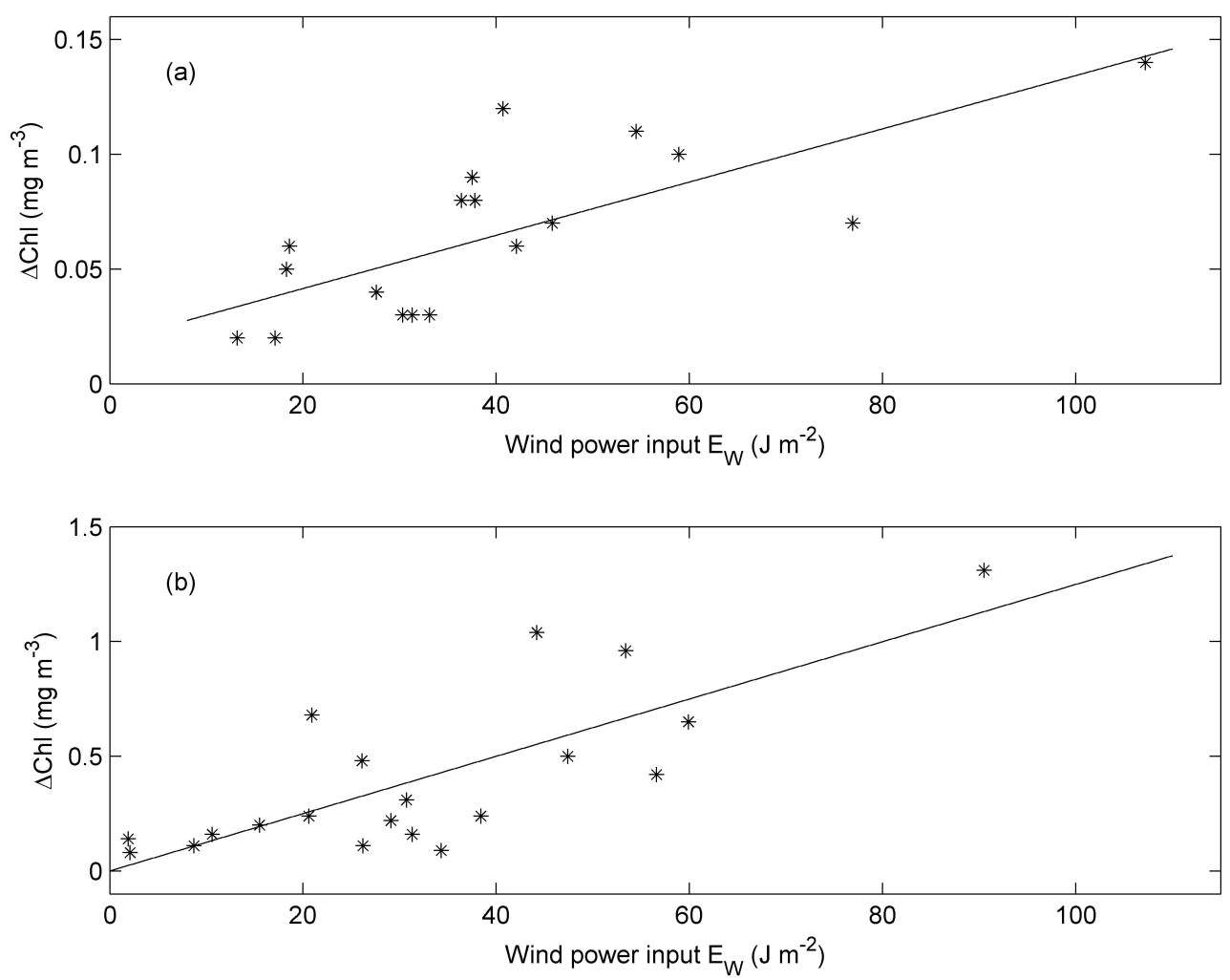

Figure 4. Linear regression of Chl-a increase to wind power input, $E_{W}$, representing the ocean upper layer mixing parameter in the NWP (a) and the SCS (b). The asterisks show the observations and the solid lines are the regressions.

The regressions of the Chl-a increase to the Ekman pumping and wind-forcing parameters indicate that there exists strong a positive correlation between the Chl-a increase and both the wind-related parameters.

An important initial condition affecting the influence of a typhoon is the mixed-layer depth [30]. We explore the relationship between the Chl-a increase and the pre-typhoon mixed-layer depth. Figure 5 shows the Chl-a increase versus the mixed-layer depth for the different typhoon cases in the NWP (a) and the SCS (b). It is found that a negative correlation exists between the Chl-a increase and the MLD. The regression can be derived by the Chl-a and the MLD data listed in Tables 1 and 2. For the NWP, the regression is given by

$$
\Delta C h l=-0.0014 H_{M L D}+0.1020
$$

The $\mathrm{R}^{2}$ value is 0.13 and the rms of the difference between the regression and the observed values is $0.034 \mathrm{mg} \cdot \mathrm{m}^{-3}$ (Table 3). Although the higher bound of the coefficient of $H_{M L D}$ is positive at the $95 \%$ confidence level (Table 3), the general trend of the relationship between the $\triangle C h l$ and the $H_{M L D}$ is a negative correlation. The linear regression for the South China Sea is also obtained with an $\mathrm{R}^{2}$ value of 0.13 and an $\mathrm{rms}$ of $0.34 \mathrm{mg} \cdot \mathrm{m}^{-3}$ (Table 3 ), written as

$$
\Delta C h l=-0.0176 H_{M L D}+0.8725
$$



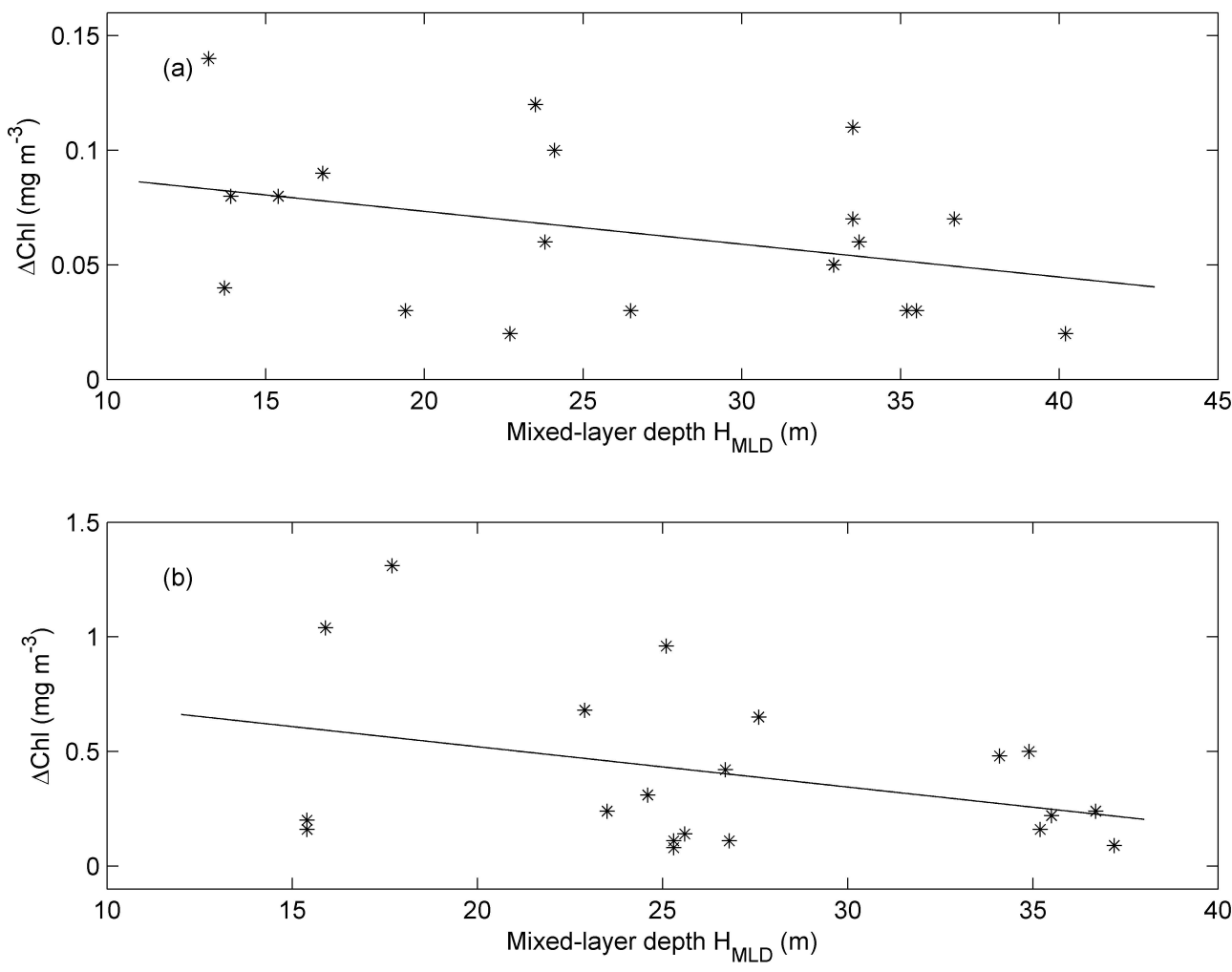

Figure 5. Linear regression of Chl-a increase to pre-typhoon mixed-layer depth in the NWP (a) and the SCS (b). The asterisks show the observations and the solid lines are the regressions.

Comparing the relationship between the Chl-a increase and the parameters of the Ekman pumping and the wind-induced mixing reveals that the correlation of $\Delta C h l$ with the MLD is of lower magnitude and oppositely orientated (negative) with higher rms values. The results demonstrate that although the Chl-a increase is more sensitive to the wind-forcing parameters, Chl-a blooms are also influenced by the pre-typhoon mixed-layer depth.

Based on these analyses, the Chl-a increase is correlated with all parameters: the Ekman pumping intensity, the wind-induced mixing, and the pre-typhoon mixed-layer depth. The impact of the mixed-layer depth can be seen by comparison between the cases of Linfa (2009) and Xangsane (2006) over the SCS (Table 2). The Ekman pumping and the wind power input parameters were $22.4 \mathrm{~m}$ and $26.1 \mathrm{~J} \cdot \mathrm{m}^{-2}$ for Linfa (2009), higher than those for Xangsane (20.3 $\mathrm{m}$ and $20.9 \mathrm{~J} \cdot \mathrm{m}^{-2}$, respectively), but the Chl-a increase for Linfa was lower than that for Xangsane $\left(0.48 \mathrm{vs} .0 .68 \mathrm{mg} \cdot \mathrm{m}^{-3}\right)$. However, the mixed-layer depth prior to the arrival of Xangsane was $22.9 \mathrm{~m}$ less than that for Linfa $(34.1 \mathrm{~m})$, and therefore, the shallower pre-typhoon mixed-layer depth could be responsible for the higher Chl-a bloom event. The same situation can be found for other typhoon cases in the NWP (Table 1), e.g., Fitow versus Rananim.

In order to develop a quantitative model of Chl-a blooms, it is necessary to consider the effect of the pre-typhoon mixed-layer depth. Thus, a multi-parameter model is suggested as

$$
\Delta C h l=a \frac{L_{E K M}{ }^{m} E_{W}{ }^{n}}{H_{M L D}{ }^{k}}+b
$$

where $a$ and $b$ are the model coefficients, and $m, n$, and $k$ are exponents of $L_{E K M}$, and $E_{W}$, and $H_{M L D}$, respectively. This quantification model can account for the positive correlations of $\Delta C h l$ with the Ekman pumping and the wind-induced mixing as well as the negative correlation with the mixed-layer depth. Equation (12) therefore represents a power-law model. Based on the typhoon and mixed-layer data in Tables 1 and 2, the coefficients $(a$ and $b)$ and the exponents $(m, n$, and $k)$ can be determined using 
a nonlinear fitting method in the MATLAB to derive the coefficients and the exponents. The results for these values are listed in Table 4 . In the NWP, $m, n$, and $k$ are $0.26,0.37$, and 0.16 , respectively, the $\mathrm{R}^{2}$ value of the regression is 0.62 , and the rms is $0.025 \mathrm{mg} \cdot \mathrm{m}^{-3}$. In the SCS, the exponents, $m, n$, and $k$ are $0.63,0.46$, and 1.2 with the $\mathrm{R}^{2}$ value of 0.80 and the rms value of $0.18 \mathrm{mg} \cdot \mathrm{m}^{-3}$ (Table 4 ). The $p$-values of the nonlinear regression model are also derived to reveal the confidence level of the nonlinear fitting. The $p$-values for the NWP and the SCS fittings are $5.9 \times 10^{-3}$ and $4.4 \times 10^{-5}$, respectively, both of which are relatively small, suggesting that the quantification model is significant (with confidence level much higher than 95\%) against the null hypothesis.

Table 4. Multi-parameter quantification of $\Delta C h l$ by the Ekman pumping, wind-induced mixing, and mixed-layer depth parameters.

\begin{tabular}{ccccccccc}
\hline Region & $\boldsymbol{a}$ & $\boldsymbol{m}$ & $\boldsymbol{n}$ & $\boldsymbol{k}$ & $\boldsymbol{b}$ & $\mathbf{R}^{\mathbf{2}}$ & $\begin{array}{c}\mathbf{R M S} \\
\left(\mathbf{m g} \cdot \mathbf{m}^{-3}\right)\end{array}$ & $\boldsymbol{p}$-value \\
\hline NWP & 0.018 & 0.26 & 0.37 & 0.16 & -0.018 & 0.62 & 0.025 & $5.9 \times 10^{-3}$ \\
SCS & 0.60 & 0.63 & 0.46 & 1.2 & 0.028 & 0.80 & 0.18 & $4.4 \times 10^{-5}$ \\
\hline
\end{tabular}

The results in the NWP show that although the multi-parameter model does not yield an improved rms value compared with the regression to $L_{E K M}$, the $\mathrm{R}^{2}$ value is higher than that of the regression to $L_{E K M}(0.62$ versus 0.56$)$. However, the implementation of the multi-parameter quantification model achieves significant improvements for the SCS. The $\mathrm{rms}$ is $0.18 \mathrm{mg} \cdot \mathrm{m}^{-3}$, much lower than those of $\Delta C h l$ regressions to the $L_{E K M}$ and $E_{W},\left(0.27 \mathrm{mg} \cdot \mathrm{m}^{-3}\right.$ and $0.23 \mathrm{mg} \cdot \mathrm{m}^{-3}$, respectively), and the $\mathrm{R}^{2}$ value is 0.80 , much greater than those of the regressions to $L_{E K M}$ and $E_{W}(0.47$ and 0.59 , respectively). The comparisons between the predicted Chl-a increase from our quantification model and the observations are illustrated in Figure 6 in the NWP (a) and the SCS (b). These regressions are close to a 1:1 relationship, especially in the SCS (Figure 6b). Compared with Figures 3-5 that show the single-parameter regressions, Figure $6 \mathrm{~b}$ demonstrates significant improvement in the prediction of Chl-a blooms in the SCS by using the multi-parameter quantification model. For the SCS, the exponent of the mixed-layer depth (1.2) is higher than that for the NWP (0.16), which suggests the change of Chl-a is more sensitive to the mixed-layer depth in the SCS than in the NWP. The multi-parameter quantification model may therefore be more suitable for analysis of typhoon-induced Chl-a blooms in the SCS than in the NWP.
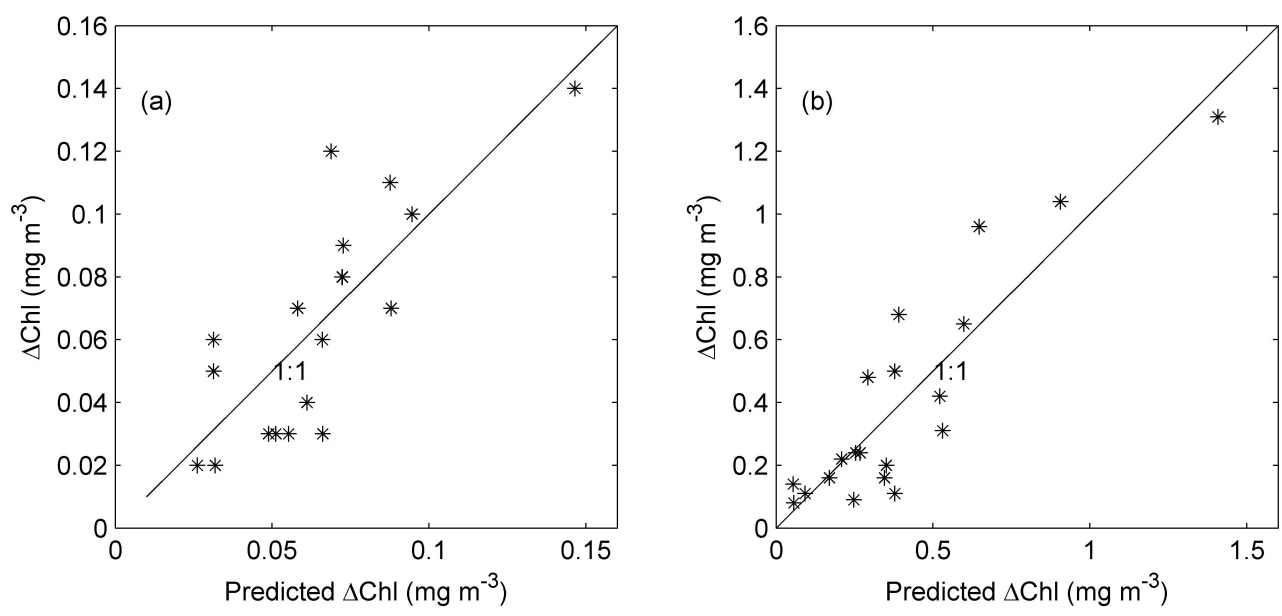

Figure 6. Multi-parameter quantification of typhoon-induced Chl-a bloom strength based on Ekman pumping, wind power input, and mixed-layer depth parameters in the NWP (a) and the SCS (b). The $\mathrm{x}$-axis shows the model predicted Chl-a increase and the $\mathrm{y}$-axis denotes the observed Chl-a increase. Solid lines show a 1:1 relationship. 


\section{Discussions}

The Chl-a bloom intensity in the SCS is much higher than that in the NWP, which can be revealed by the higher coefficients of $p 1$ (Table 3 ) for the single-parameter linear regressions and of $a$ (Table 4 ) for the multi-parameter quantification model in the SCS. Thus, the typhoon-induced Chl-a concentration increases in the SCS are more intensive than those in the NWP. This difference is mainly caused by the different nutrient levels observed in the NWP and the SCS. In the upper ocean, nutrients play an important role in phytoplankton variation [31,32]. In order to compare nutrient levels for these different regions, a section is selected across the NWP and the SCS (the black line in Figure 7a). Figure $7 \mathrm{~b}$ displays the profiles of the nitrate concentration along this section based on the data of the 2009 World Ocean Atlas (WOA) obtained from the website of National Centers for Environmental Information (NCEI) of the U.S. National Oceanic and Atmospheric Administration (NOAA) [33]. In the SCS, although the nitrate concentration is less than $5 \mu \mathrm{mol} \cdot \mathrm{L}^{-1}$ in the upper $50 \mathrm{~m}$, it increases to $15 \mu \mathrm{mol} \cdot \mathrm{L}^{-1}$ between 50 and $200 \mathrm{~m}$. In the NWP, however, the nitrate concentration always keeps a level less than $5 \mu \mathrm{mol} \cdot \mathrm{L}^{-1}$ in the upper $300 \mathrm{~m}$; only in the Luzon strait, the nitrate concentration reaches the value of $5 \sim 10 \mu \mathrm{mol} \cdot \mathrm{L}^{-1}$. This suggests that the SCS has more abundant nutrients in its subsurface than the NWP, and the surface water can obtain more nutrient supplies from the subsurface once influenced by strong typhoon wind forcing. Light intensity may also affect $\mathrm{Chl}$-a blooms, and the SCS, which is at a low latitude, generally receives more illumination than the NWP, which could be another reason for higher Chl-a increases in the SCS after typhoon passes.
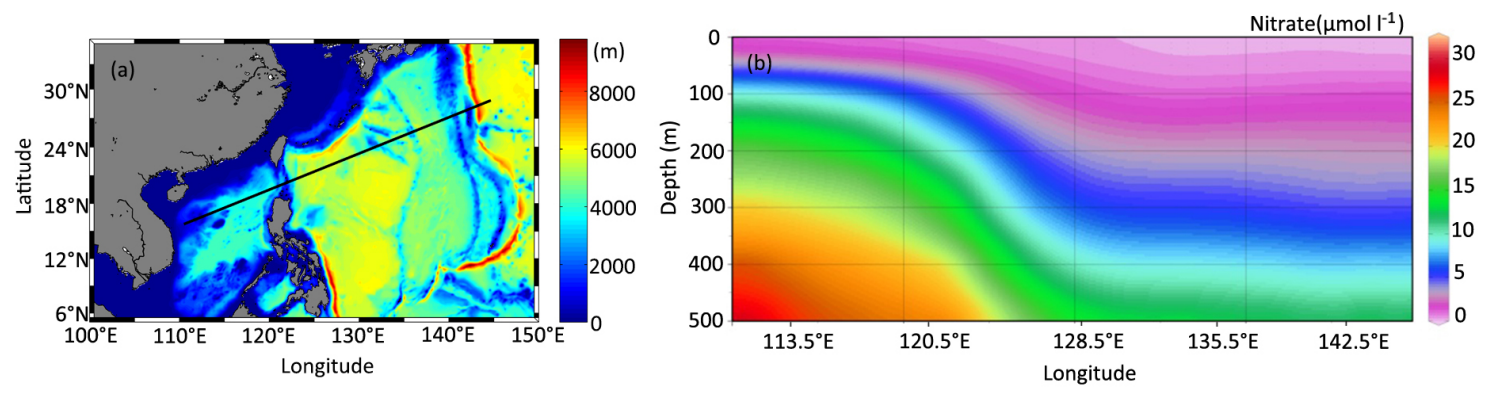

Figure 7. A section (the black line) across the NWP and the SCS in which the bathymetry is shown in color (a) and the climatological profiles of the nitrate concentration $\left(\mu \mathrm{mol} \cdot \mathrm{L}^{-1}\right)$ in summer along the section $(\mathbf{b})$.

Previous studies have shown that meso-scale eddies with spatial scales of $\sim 10^{2} \mathrm{~km}$ can influence phytoplankton variation in the ocean surface and the eddy-induced vertical flux of nutrients may influence the nutrient budget; cyclonic eddies (cold) may boost growth of surface phytoplankton, and anticyclonic eddies (warm) decrease phytoplankton level in the cores but increase it in the peripheries [34-38]. However, under typhoon conditions, the eddy-induced vertical flux is much weaker than that generated by the strong wind-forcing, and may not significantly affect Chl-a bloom strength. Thus, the pre-typhoon mixed-layer depth changes caused by meso-scale eddies could be an important dynamical factor influencing Chl-a blooms under typhoon conditions. On the other hand, pre-existing meso-scale eddies may be modified by strong wind forcing, and therefore, the vertical flux caused by eddies could be changed as well. The nutrient level varies by location, and the impact of nutrient level changes on the quantification of the Chl-a bloom will be investigated in future studies along with consideration of a detailed eddy-related dynamic process during typhoon forcing by analyzing more storm cases.

Using remote sensing observations, there were many studies showing that under stormy conditions, sea surface Chl-a increases are attributed to the enhanced nutrient supplies caused by the upwelling and vertical mixing $[4,13-15,39]$. Strong typhoon winds may induce massive entrainment of air bubbles into the water column through the wave breaking; these bubbles have a spectral effect on 
ocean reflectance, and therefore, the bubble entrainment may affect the estimation accuracy of surface Chl-a concentration from remote sensing observations [40]. In situ measurements from a Bio-Argo float with fluorescence method to detect the Chl-a concentration located at the central Bay of Bengal indicate that there was substantial Chl-a increase (to as high as $4.5 \mathrm{mg} \cdot \mathrm{m}^{-3}$ ) induced by a tropical cyclone, Hudhud, and the Bio-Argo observations on the Chl-a profiles suggest that the nutrient inject is a major reason for the Chl-a increase under the storm condition, leading to the chlorophyll bloom [41]. Nevertheless, the effect of the air bubbles on the Chl-retrieval under the storm condition does need further investigations to improve Chl-a algorithms for satellite ocean-color observations.

Tables 1 and 2 show that the Chl-a increases are lower than the detection threshold of the Chl-a from satellite observations (e.g., $0.02 \mathrm{mg} \cdot \mathrm{m}^{-3}$ in Table 1 and $0.08 \mathrm{mg} \cdot \mathrm{m}^{-3}$ in Table 2). Since these Chl-a increase values in Tables 1 and 2 are averaged over certain temporal and spatial ranges, the average process may substantially reduce the detection uncertainty for the satellite Chl-a, and also smooth the Chl-a values. The smoothed Chl-a values are lower than Chl-a bloom peaks. The maximum Chl-a increase in Table 2 (for the SCS) is below $1.5 \mathrm{mg} \cdot \mathrm{m}^{-3}$, whereas the peak of the surface Chl-a bloom could be as high as $\sim 3.0 \mathrm{mg} \cdot \mathrm{m}^{-3}$ [41]. Although the Chl-a data used to develop the multi-parameter quantification model are below $1.5 \mathrm{mg} \cdot \mathrm{m}^{-3}$ for the SCS, this data set may represent most of Chl-a bloom cases in the area. It is expected that with different regression coefficients, the multi-parameter quantification model could be applied in other regions.

\section{Conclusions}

Tropical cyclones can induce Chl-a blooms by enhancing the vertical transport of the nutrients from the subsurface water. The Chl-a bloom strength may be related to wind-forcing parameters and the oceanic initial conditions. In this study, Ekman pumping and wind-induced mixing parameters (defined as the integral of the upwelling velocity and the wind input power, respectively) and the pre-typhoon mixed layer depth are used to model Chl-a increase as influenced by typhoons in the Northwest Pacific (NWP) and the South China Sea (SCS). The linear regression suggests that in the $\mathrm{NWP}$, the typhoon-induced Chl-a increase is correlated with the Ekman pumping parameter with a regression $\mathrm{rms}$ of $0.024 \mathrm{mg} \cdot \mathrm{m}^{-3}$ and an $\mathrm{R}^{2}$ value of 0.56 , while in the SCS, the $\mathrm{R}^{2}$ value is 0.47 and the $\mathrm{rms}$ is $0.27 \mathrm{mg} \cdot \mathrm{m}^{-3}$.

A multi-parameter quantification model of the Chl-a blooms is develop to consider the joint effects of Ekman pumping, wind-induced mixing, and pre-typhoon mixed-layer depth. The results show that in the SCS, our model achieves satisfactory results, with an $\mathrm{R}^{2}$ value as high as 0.80 , much higher than that seen in the single-parameter regressions, and also achieves the lowest $\mathrm{rms}\left(0.18 \mathrm{mg} \cdot \mathrm{m}^{-3}\right)$. For the multi-parameter quantification in the NWP, the $\mathrm{R}^{2}$ value is improved, although the rms is similar to that of the single-parameter regression for the Ekman pumping. The multi-parameter quantification works better in the SCS than in the NWP. This may be due to the fact that in the NWP, nutrient profiles are uniform from surface to a deep depth $(300 \mathrm{~m})$, while the SCS has a shallow nutricline, and therefore, sub-surface high level of nutrients can be easily brought into the surface in the SCS as affected by the typhoon forcing.

Acknowledgments: This study is jointly supported by the National Natural Science Foundation of China under project 41376035, the National Basic Research Program of China (2015CB954103), the General Research Fund of Hong Kong Research Grants Council (RGC) under grants CUHK 402912 and 403113, the Hong Kong Innovation and Technology Fund under the grants of ITS/259/12 and ITS/321/13, and the direct grants of the Chinese University of Hong Kong. The authors are also grateful to the anonymous reviewers for their valuable suggestions and comments.

Author Contributions: J.P. conceived and designed this study, worked on the development of the multi-parameter quantification model, and wrote the paper; L.H. conducted the data collection and processing; A.T.D. carefully edited the English and implemented the partial analysis of the results; H.L. helped the result interpretation, and provided comments and suggestions on the paper.

Conflicts of Interest: The authors declare no conflict of interest. 


\section{References}

1. Price, J.F. Upper ocean response to a hurricane. J. Phys. Oceanogr. 1981, 11, 153-175. [CrossRef]

2. Greatbatch, R.J. On the response of the ocean to a moving storm: The nonlinear dynamics. J. Phys. Oceanogr. 1983, 13, 357-367. [CrossRef]

3. Dickey, T.; Frye, D.; McNeil, J.; Manov, D.; Nelson, N.; Sigurdson, D.; Jannasch, H.; Siegel, D.; Michaels, T.; Johnson, R. Upper-ocean temperature response to Hurricane Felix as measured by the Bermuda Testbed Mooring. Mon. Wea. Rev. 1998, 126, 1195-1201. [CrossRef]

4. Lin, I.I.; Liu, W.T.; Wu, C.C.; Wong, G.T.; Hu, C.; Chen, Z.; Liu, K.K. New evidence for enhanced ocean primary production triggered by tropical cyclone. Geophys. Res. Lett. 2003, 30, 1718. [CrossRef]

5. Sanford, T.B.; Price, J.F.; Girton, J.B. Upper-ocean response to hurricane Frances (2004) observed by profiling EM-APEX floats. J. Phys. Oceanogr. 2011, 41, 1041-1056. [CrossRef]

6. Tseng, Y.; Jan, S.; Dietrich, D.E.; Lin, I.; Chang, Y.; Tang, T. Modeled oceanic response and sea surface cooling to Typhoon Kai-Tak. Terr. Atmos. Ocean Sci. 2010, 21, 85-98. [CrossRef]

7. Cheung, H.F.; Pan, J.; Gu, Y.; Wang, Z. Remote sensing observation of ocean responses to the Typhoon Lupit in the Northwest Pacific. Int. J. Remote Sens. 2013, 34, 1478-1491. [CrossRef]

8. Lin, I.I.; Pun, I.F.; Wu, C.C. Upper-ocean thermal structure and the western North Pacific category 5 typhoons. Part II: Dependence on translation speed. Mon. Wea. Rev. 2009, 137, 3744-3757. [CrossRef]

9. Zedler, S.E.; Dickey, T.D.; Doney, S.C.; Price, J.F.; Yu, X.; Mellor, G.L. Analyses and simulations of the upper ocean's response to Hurricane Felix at the Bermuda Testbed Mooring site: 13-23 August 1995. J. Geophys. Res. 2002, 107, 25-1-25-29. [CrossRef]

10. Jacob, S.D.; Shay, L.K.; Mariano, A.J.; Black, P.G. The 3D mixed layer response to Hurricane Gilbert. J. Phys. Oceanogr. 2000, 30, 1407-1429. [CrossRef]

11. Jacob, S.D.; Shay, L.K. The role of mesoscale features on the tropical cyclone-induced mixed layer response: A case study. J. Phys. Oceanogr. 2003, 33, 649-676. [CrossRef]

12. Pan, J.; Sun, Y. Estimate of ocean mixed layer deepening after a typhoon passage over the south china sea by using satellite data. J. Phys. Oceanogr. 2013, 43, 498-506. [CrossRef]

13. Babin, S.M.; Carton, J.A.; Dickey, T.D.; Wiggert, J.D. Satellite evidence of hurricane induced phytoplankton blooms in an oceanic desert. J. Geophys. Res. 2004, 109, 1978-2012. [CrossRef]

14. Zheng, G.; Tang, D. Offshore and nearshore chlorophyll increases induced by typhoon winds and subsequent terrestrial rainwater runoff. Mar. Ecol. Prog. Ser. 2007, 333, 61-74. [CrossRef]

15. Shang, S.; Li, L.; Sun, F.; Wu, J.; Hu, C.; Chen, D.; Shang, S. Changes of temperature and bio-optical properties in the South China Sea in response to Typhoon Lingling. Geophys. Res. Lett. 2008, 35, L10602. [CrossRef]

16. Stramma, L.; Cornillon, P.; Price, J.F. Satellite observations of sea surface cooling by hurricanes. J. Geophys. Res. 1986, 91, 5031-5035. [CrossRef]

17. Nelson, N.B. Spatial and temporal extent of surface ocean modifications by hurricanes during the 1995 season. Mon. Wea. Rev. 1998, 126, 1364-1368. [CrossRef]

18. Zhao, H.; Tang, D.; Wang, Y. Comparison of phytoplankton blooms triggered by two typhoons with different intensities and translation speeds in the South China Sea. Mar. Ecol. Prog. Ser. 2008, 365, 57-65. [CrossRef]

19. Tsai, Y.; Chern, C.S.; Wang, J. The upper ocean response to a moving typhoon. J. Phys. Oceanogr. 2008, 64, 115-130. [CrossRef]

20. Zheng, Z.W.; Ho, C.R.; Kuo, N.J. Importance of pre-existing oceanic conditions to upper ocean response induced by Super Typhoon Hai-Tang. Geophys. Res. Lett. 2008, 35, L20603. [CrossRef]

21. Zheng, Q.; Tai, C.K.; Hu, J.; Lin, H.; Zhang, R.H.; Su, F.C.; Yang, X. Satellite altimeter observations of nonlinear Rossby eddy-Kuroshio interaction at the Luzon Strait. J. Oceanogr. 2011, 67, 365-376. [CrossRef]

22. Lin, I.I.; Wu, C.C.; Emanuel, K.A.; Lee, H.I.; Wu, C.R.; Pun, I.F. The interaction of Super typhoon Maemi (2003) with a warm ocean eddy. Mon. Wea. Rev. 2005, 133, 2635-2649. [CrossRef]

23. QuikScat/SeaWinds. Available online: http:/ / www.remss.com/missions/qscat (accessed on 31 January 2017).

24. Copernicus. Available online: http:/ / www.copernicus.eu/ (accessed on 31 January 2017).

25. Guinehut, S.; Le Traon, P.Y.; Larnicol, G.; Philipps, S. Combining Argo and remote-sensing data to estimate the ocean three-dimensional temperature fields-A first approach based on simulated observations. J. Mar. Syst. 2004, 46, 85-98. [CrossRef] 
26. Guinehut, S.; Dhomps, A.L.; Larnicol, G.; Le Traon, P.Y. High resolution 3D temperature and salinity fields derived from in situ and satellite observations. Ocean Sci. 2012, 8, 845-857. [CrossRef]

27. Unisys Weather. Available online: http://weather.unisys.com/hurricane/w_pacific (accessed on 31 January 2017).

28. Shay, K.L.; Elsberry, R.L.; Black, P.G. Vertical structure of the ocean current response to a hurricane. J. Phys. Oceanogr. 1989, 19, 649-669. [CrossRef]

29. Simpson, J.H.; Brown, J.; Matthews, J.; Allen, G. Tidal straining, density currents, and stirring in the control of estuarine stratification. Estuaries 1990, 13, 125-132. [CrossRef]

30. Huang, L.; Zhao, H.; Pan, J.; Devlin, A. Remote sensing observations of phytoplankton increases triggered by successive typhoons. Front. Earth Sci. 2017, 11, 601-608. [CrossRef]

31. Furuya, K. Subsurface chlorophyll maximum in the tropical and subtropical western Pacific Ocean: Vertical profiles of phytoplankton biomass and its relationship with chlorophyll a and particulate organic carbon. Mar. Biol. 1990, 107, 529-539. [CrossRef]

32. Yentsch, C.S.; Charles, S. Distribution of chlorophyll and phaeophytin in the open ocean. Deep-Sea Res. Oceanogr. Abstr. 1965, 12, 653-666. [CrossRef]

33. World Ocean Database and World Ocean Atlas Series. Available online: https://www.nodc.noaa.gov/OC5/ indprod.html (accessed on 31 January 2017).

34. McGillicuddy, D.J.; Robinson, A.R.; Siegel, D.A.; Jannasch, H.W.; Johnson, R.; Dickey, T.D.; McNeil, J.; Michaels, A.F.; Knap, A.H. Influence of mesoscale eddies on new production in the Sargasso Sea. Nature 1998, 394, 263-266. [CrossRef]

35. Sasai, Y.; Richards, J.; Ishida, A.; Sasaki, H. Effects of cyclonic mesoscale eddies on the marine ecosystem in the Kuroshio Extension region using an eddy-resolving coupled physical-biological model. Ocean Dynam. 2010, 60, 693-704. [CrossRef]

36. Piontlovsky, S.A.; Nezlin, N.P.; Al-Azri, A.; Al-Hashmi, K. Mesoscale eddies, and variability of chlorophyll-a in the Sea of Oman. Int. J. Remote Sens. 2012, 33, 5341-5346. [CrossRef]

37. Kouketsu, S.; Kaneko, H.; Okunishi, T.; Sasaoka, K.; Itoh, S.; Inoue, R.; Ueno, H. Mesoscale eddy effects on temporal variability of surface chlorophyll a in the Kuroshio Extension. J. Oceanogr. 2016, 72, 439-451. [CrossRef]

38. Kahru, M.; Mitchell, B.G.; Gille, S.T.; Hewes, C.D.; Holm-Hansen, O. Eddies enhance biological production in the Weddell-Scotia Confluence of the Southern Ocean. Geophys. Res. Lett. 2007, 34, L14603. [CrossRef]

39. Shi, W.; Wang, M. Observations of a Hurricane Katrina induced phytoplankton bloom in the Gulf of Mexico. Geophys. Res. Lett. 2007, 34, L11607. [CrossRef]

40. Stramski, D.; Tegowski, J. Effects of intermittent entrainment of air bubbles by breaking wind waves on ocean reflectance and underwater light field. J. Geophys. Res. 2001, 106, 31,345-31,360. [CrossRef]

41. Chacko, N. Chlorophyll bloom in response to tropical cyclone Hudhud in the Bay of Bengal: Bio-Argo subsurface observations. Deep-Sea Res. Part I 2017, 124, 66-72. [CrossRef] 